\title{
1
}

\section{Food Anxiety: Ambivalences Around Body and Identity, Food Safety, and Security}

\section{Judith Ehlert and Nora Katharina Faltmann}

Imagine wandering around an open food market, tempted to satiate your appetite with something fresh and delicious. You come across a market vendor who displays a large pile of something on a silver tray. Given the view of a throng of curvy-shaped knotty things, you are puzzled to distinguish the actual boundaries between these nearly transparent objects. Only at second look, this bunch turns out to be a catch of dead shrimps with their visceral organs shining through, some with their heads torn off, some with intact bodies. Meanwhile a range of scents is in the air, some appetising, others perhaps more alien. Imagine being the viewer of this scene, what does it arouse in you? Depending on your perspectiveeating habits and socio-cultural background, current sensation of hunger, perception of the quality, or knowledge of the surroundings-either delight or disgust.

This book is explicitly about such ambivalences of food ranging between delight and disgust. The described scenario could evoke anxiety in the viewer while others might be drawn to the food in question. At the

J. Ehlert $(\bowtie) \bullet$ N. K. Faltmann

Department of Development Studies, University of Vienna, Vienna, Austria e-mail: judith.ehlert@univie.ac.at; nora.faltmann@univie.ac.at 
same time, the scenario hints at the split seconds in which humans make something out as edible or not. According to the 'omnivore's paradox', human food consumption is navigated between the sheer abundance of things that could be eaten physiologically but are constrained by the social and cultural norms that define food and produce as edible or inedible, as symbolically enhanced or contaminated in the first place (Rozin 1976; Fischler 1988). Moreover, the categorisation of 'edible'/ inedible' is historically rooted in peoples' trial and error experiments with potentially harmful substances (Rozin 1976; Fischler 1988). Food can make you sick or keep you healthy, can leave you overindulged or hungry, can nurture social belonging but can also blatantly expose social exclusion. Historical and socio-cultural experiences, norms and discourses around material and symbolic quality can then mark food as pure or dangerous, and as friend or foe by the same token. This ambivalent nature of eating lies at the very heart of the human encounter with food as both matter and meaning and constitutes the lynchpin of this volume.

Whereas food is already amply discussed in terms of culinary 'delight' by putting at centre stage the role of food allocation in the creation and maintenance of social relationships, commensality, and cohesion, ${ }^{1}$ this book rather engages with the conflictive externalities and local embeddedness of a globalised agri-food system, namely by bringing eating in Vietnam into perspective. The ambivalent and potentially disturbing nature that food can have is reflected in this volume's cover image ${ }^{2}$ : photographed at an open market in Ho Chi Minh City (HCMC), with the depicted shrimps exemplifying the interconnectedness of global food systems and their embeddedness in Vietnam. With its cultivation at times competing with less lucrative rice growing, and subject to food safety concerns and as regimented item in global trade, shrimp commodity chains symbolise the complexity of global food trade.

Vietnam proves to be an excellent case to depict the diverse facets of food ambivalence given the country's historical context and compressed integration into global (food) markets. Its past-and in parts currentexperience of food scarcity and hunger has created challenges of how to meaningfully manoeuvre in a context of emerging food abundance. Against this dynamic background in (urban) Vietnam, people's bodily integrity and identity, gendered and class-based consumption, and 
concerns of food safety and security all touch upon-in one way or another-the ambiguous nature of food itself, and also indicate discontinuities of broader social transformations.

Food anxiety is the book's common lens through which such ambiguities are considered. The very act of incorporating food constitutes the moment and the process in which materially and culturally transformed matter crosses the boundary of the body, thereby dissolving the dichotomy between 'inside' and 'outside', between the self and the world (Fischler 1988, 279). In this understanding, boundaries are crossed at various scales, connecting but also disconnecting the eating body with the multiple contexts it lives in. It is exactly the linking and disrupting quality of foodstuff-a food's transgressive capacity (Goodman and Sage 2014) — that accounts for its ambivalent nature and makes us speak of 'food anxiety'. Therein, we understand the lens of food anxiety as constitutive for unravelling social theoretical insights into the relationship between the individual and society. ${ }^{3}$ What we observe in the vast field of food-related literature is that 'food anxiety' is more often than not used without further conceptual explanation or becomes boiled down to paramount incidences of food scandals. ${ }^{4}$ We argue that 'food anxiety' has more to offer than being a descriptive term for the emotional and institutional management of food safety risks, as we will detail below. This volume brings together authors from various disciplines and while their contributions are united in that they all deal with dimensions of food anxiety in Vietnam, the authors follow their own distinct methodological and theoretical approaches to food. Likewise, this introductory chapter should be seen as one, namely the editors' interpretation of what follows in the outline of the book parts. By applying our lens of food anxiety, we will frame the three thematic dimensions along which the book is organised: 'Bodily Transgressions: Identity, Othering, and Self' (Part I), 'Food Safety: Trust, Responsibilisation, and Coping' (Part II), and 'The Politics of Food Security' (Part III).

When it came to naming this edited volume, food anxiety as the contributions' mutual lens quickly asserted itself into the title. Since all contributions focus on Vietnam, adding the country's name was also an easy decision. But then it took multiple attempts of testing the conceptual sound of 'Vietnam and beyond' and the like to finally come down with 
what is now the title of this book: Food Anxiety in Globalising Vietnam. In hindsight, the title seems almost inevitable as this book is not about a country and beyond but rather about the (globalising) dynamics of beyond in Vietnam. Bringing in our own perspective from the field of critical development studies, we find it important to stress the 'dynamics of beyond'. In the (food studies) literature we observe that the mentioned strong focus on the quality of food is very often connected with the Global North. It is, sometimes indirectly, sometimes more overtly assumed that 'the consumer' in the Global North is most concerned with quality and safety due to the food abundance provided by a modernised (agri-)food system. Thus, consumers in the Global North are presented as constantly calculating risks in their daily endeavour to eat clean and healthy food, whereas lack of food access-even though a social reality for many ${ }^{5}$ - is much less discussed. By contrast, the Global South is generalised as struggling with not having enough to eat and set as an umbrella term essentialising deficiencies more generally. Yet, we find it more fruitful to contextualise such 'food struggles' along the lines of class, gender, and race and as symptoms of locally embedded capitalist structures bound up in the complex web of historical food trajectories. Besides the editors' innate interest in such dynamics around food availability and consumerism in Vietnam motivating the compilation of this edited volume, there was also a desire to contribute to literature given the relative paucity of existing research on this topic. Particularly from multidisciplinary angles, the area of food and anxiety in a wider sense has not yet received the academic attention that we believe it deserves in order to understand societal relations and transformations in Vietnam. Therefore, the twofold aim of this book is to contribute to research on the field of food in Vietnam as well as on phenomena of food anxiety more broadly.

Having made this point, it will become apparent throughout much of this book that many forms of food anxiety in current-day globalising Vietnam cannot be understood without the context of the country's rapid and recent economic integration into global agri-food systems and consumer markets. Therefore, we want to begin with examining the trajectories of the globalised agri-food system that Vietnam has grown to be increasingly intertwined with. We will then sharpen the lens of food anxiety conceptually. By portraying the book's contributions and the way 
they all speak — in yet different ways — to food anxiety, this will then lead us to discuss concrete examples of what it means to be anxious in terms of food consumption and production in Vietnam. The book ends with concluding remarks by Jean-Pierre Poulain in which he discusses the value of 'food anxiety' as a conceptual lens for understanding broader societal transformations. He argues that because food anxiety is able to capture contemporary crises ranging from food security and food fraud to social controversies, it offers the perspective for a more global analysis of the relation of humans to food.

\section{Food in Globalising Vietnam}

When speaking of an agri-food system of global dimensions, the question of what globalisation means in terms of food is inevitable. Depending on discipline and school of thought, the definitions of food globalisation and its beginnings vary widely. Referring to "food globalizations" (Inglis and Gimlin 2009, 4) in the plural mirrors the heterogeneous and at times contradicting dialectic relations of food matters with the social, economic, political, and cultural dimensions of globalisation (Inglis and Gimlin 2009, 9). While the travel of food has been a constant in human history and migration, it can be said that especially the nineteenth and twentieth centuries saw the spread of a mode of food production, distribution, and consumption that has become increasingly globe-spanning in nature (Inglis and Gimlin 2009, 13f.). The dissemination of industrial agriculture and factory farming, local integration into capitalist markets and trade liberalisation, food technology as much as global cargo transport were major factors in the spread of global agri-food systems (Beardsworth and Keil 1997).

These global dynamics also reflect-in locally unique manifestationsVietnam's (agri-)food history which we will contextualise along with the global food regimes of political economists Friedmann and McMichael (Friedmann and McMichael 1989; McMichael 2009). Food regime theory problematises the capitalist evolution of globalised agriculture as the outcome of an unequal structural power play between different world regions. In general, the European ideology of racial superiority over 
'backward' colonies in need of 'civilisation' marked the cornerstone of the development of a global yet highly unequal capitalist system of agricultural modernisation, industrialisation, and trade. During nineteenthcentury colonialism, expanding projects of Western civilisation forced the world to participate in a market economy controlled by global colonial regimes, competing forcefully for the raw materials and markets in the colonised Global South. In Vietnam as elsewhere, colonial hegemonic power was ideologically based on constructed racial superiority, forcefully implemented on the bases of science, industrial might, and Christian norms (Jamieson 1995, 42). Industrialisation in Europe required the social reorganisation of labour from national agriculture into industrial factory work. In the 'colonial-diasporic regime'-as the first of three global food regimes-extensive land exploitation and mono-cropping in the colonies of the Global South literally fed the emerging national industries in Europe (Friedmann and McMichael 1989). In Vietnam, it was especially the rich resource base and the water-based transport potential of the Mekong Delta in the country's south that attracted the French colonial gaze. ${ }^{6}$ Following the European 'masterplan' of capitalist growth, French colonial force was first imposed on the southern region of Vietnam in the 1860s before establishing rule in the central and northern regions later on. ${ }^{7}$ Colonial domination triggered the First Indochina War (1946-1954), and finally culminated in the defeat of the French regime in 1954 and tore Vietnam in two, with the communist Democratic Republic of Vietnam in the north and the US-backed capitalist Republic of Vietnam in the south (Jamieson 1995, 232f.).

What then followed in terms of geopolitical struggles and agricultural developments in separated North and South Vietnam during the Second Indochina War (1955-1975) ${ }^{8}$ could be subsumed under what Friedmann and McMichael coined the 'mercantile-industrial regime' ranging from the 1950 s to the 1970 s and founded in agro-industrialisation and stateprotectionism (McMichael 2009, 143). During the second global food regime and the post-colonial independence in the Global South, the communist bloc and the 'free world' of the Cold War courted the newly independent nation-states to follow their respective models of agricultural modernisation. This included the transfer of Green Revolution technology, namely the introduction of large-scale monoculture and 
irrigation schemes, the reorganisation of agricultural land and labour as well as food aid from the communist bloc and the USA, respectively. During the decades of Vietnam's separation in which blatant food insecurity prevailed, both 'Vietnams' followed different agricultural strategies to feed the war-torn civilian populations as well as military personnel. While collectivisation of agriculture in the 1950s North Vietnam did lead to increased food security of the poorest rural populations, the anticipated increases in food production failed to materialise (Jamieson 1995, 367). The government of the North's Democratic Republic of Vietnam pursued a 'technical duality' which supported agricultural mechanisation while avoiding mechanical labour replacement (Fortier and Trang Thi Thu Trang 2013, 83). Meanwhile, agriculture in capitalist shaped South Vietnam was characterised by more intense mechanisation and commercial agriculture (Fortier and Trang Thi Thu Trang 2013, 83).

After the reunification of North and South Vietnam in 1976 when the Second Indochina War had been won by the communist North in the prior year, food scarcity remained a widespread threat in the face of the country's international isolation. Domestic food production met challenges in providing the Vietnamese people with sufficient food, with the country having relied on annual aid (e.g. in the form of fertilisers and food) primarily from other socialist countries ever since the 1960s (Dang Phong 2004, 21f). Moreover, the Communist Party's attempts to collectivise agriculture in southern Vietnam were met with resistance on the side of many farmers (Ngo Vinh Long 1993; Jamieson 1995, 367f.). With decreasing production and increasing food prices, the government feared unrest in urban areas; yet, governmental attempts to make farmers sell their rice yields at low prices resulted in hoarding and black market activities rather than the desired effect of low food prices (Jamieson 1995, 367f.). Eventually, it was the synergy of multiple factors that led the Vietnamese government to revisit its development strategies and policies more broadly:

With agriculture stagnating, foreign exchange nearly exhausted, foreign aid low and shrinking, industrial capacity damaged by war, rebuilding stalled by a lack of capital, consumer goods in short supply, and per capita food consumption declining, the party began to sustain severe criticism and was forced to reverse its relentless pressure to transform Vietnam into its own vision of a utopian socialist paradise. (Jamieson 1995, 371) 
Taking stock of the obstacles to the country's food security finally galvanised the Vietnamese Communist Party into reform. What followed were the economic reforms of Đổi Mới in 1986, marking a point of departure for the country's strong integration into global (food) markets (Beresford 2001; Beresford 2008). The Đổi Mới policy initiated the transition from a centrally planned economy, fixed prices, public ownership of the means of production, and state monopoly of foreign trade towards an open market economy with acceptance of private and foreign capitalist sectors (Dang Phong 2004, 21, 37). Đổi Mới mirrored a general gradual neoliberal trend in development politics of that time (McMichael 2012, $111 \mathrm{ff}$.$) .$

Sparked by the world financial crises of the 1970s and 1980s (McMichael 2009), international bodies like the World Bank and International Monetary Fund introduced further economic liberalisation and Structural Adjustment Programs (SAPs) to countries of the Global South as supposed remedies to the crisis. SAPs entailed the deregulation of the agricultural sector and cuts in governmental and donor expenditures, agricultural specialisation towards export crops plus the removal of agricultural tariffs (Mittal 2009). This gradually paved the way for corporate food power to emerge and to flourish. The third global food regime following the 1980s ('the corporate regime') constitutes the most recent one, providing the structural background against which most of the world's food production and consumption takes place today (McMichael 2009). The latest regime is driven by the monopolised corporate power of giant agribusinesses which dominate industrial-scale agriculture from the basis of agronomy research and agricultural patents over to mass-scale monocrop- and cash crop-production. The corporate landscape is complemented by large-scale industrial food producers and manufacturers monopolising the production and retail of packaged food and drinks on a worldwide scale. The popular term 'Big Food' is drawn on when referring to the power and control of such global agri-food giants sharply influencing what the world eats (Nestlé 2013; Clapp and Scrinis 2017).

Since Vietnam's gradual liberalisation in the mid-1980s and more recently with accession to the World Trade Organisation in 2007, emerging food markets in Vietnam are increasingly teeming with agri-food businesses trying to gain a foothold. The Green Revolution with its high 
inputs of pesticides, fertilisers, and growth hormones (Simmons and Scott 2007) is backed by global agribusinesses (see Zhang, this volume). While Vietnam boosted agricultural production in recent decades and switched from being a net importer of rice to one of the world's leading rice exporters (Tran Thi Thu Trang 2011), agriculture today faces other challenges. Agricultural land, especially in peri-urban areas, has seen land use conversions towards industrialisation and urbanisation, impacting farmers' livelihoods and-coupled with a growing population-creating pressure on agricultural productivity (Nguyen Van Suu 2009; Ehlert 2012). Moreover, the impacts of climate change are already palpable in agriculture, for example, in the shape of rising sea levels and salinity intrusion, effects that are predicted to worsen with climate change (Yu et al. 2010; Smajgl et al. 2015). Exposure to weather extremes and the importance of the agricultural sector makes Vietnam particularly vulnerable to these impacts which the government has so far mitigated through technological fixes such as dykes, irrigation systems, and resistant rice varieties in line with discourses of 'modernisation' (Ehlert 2012; Fortier and Trang Thi Thu Trang 2013).

With the vision of a 'modernised' food system also stretching into retail, the Vietnamese government strongly encourages foreign and domestic capital investments in the retail sector, opening the doors for corporate power to provide for domestic supermarket shelves (Hai Thi Hong Nguyen et al. 2013). Concomitantly, the food retail system was prominently altered by the emergence of supermarkets from the early 1990 s which since have grown strongly in numbers in the country's major cities (Moustier et al. 2010, 72). Meanwhile, the prioritisation of formalised food outlets has implicated the marginalisation of informal street vendors and 'traditional' markets (Kurfürst 2012; Endres 2013).

Economic liberalisations in countries of the Global South produced a growing dependency of and vulnerability towards global markets and their prices (Mittal 2009). This became all the more apparent during the global food crisis in 2007/2008. ${ }^{9}$ While not amongst the countries most affected and despite its recent food productivity gains, the impacts of the crisis did also resonate within Vietnam. The country's entanglements in a globalised food system in crisis showed in consumer anxieties over rising rice prices, in the re-evaluation of the country's food security strategy as 
well as in the risk of small-scale producers dropping out of the farming sector (Akram-Lodhi 2004, 2005; see Gorman, this volume).

\section{From the Productivist Gaze to the 'Fruits' of Consumption}

Against the background of the global corporate food regime, food distribution networks have become as globalised as they have become obscured, and a new quality of food safety concerns, health issues, and distrust towards food have emerged and certainly also constitute one of the most publicly denounced problems with food in contemporary Vietnam (see Part II, this volume). The global span of BSE (bovin spongiform encephalopathy) originating in Europe in the 1990s, large incidences of avian flu (Inglis and Gimlin 2009, 20), and the contamination of baby formula with melanin in China (Jackson 2015) are but a few of many contemporary food safety concerns. These are often seen as related to the globalised food system's structural characteristic of 'distanciation' between food production and consumption and between the realms of the rural and the urban (Bricas 1993; Wilk 2009; Figuié and Bricas 2010). In the same vein, Poulain $(2017,9)$ speaks of the characteristic of "[m] odern food" that "has been delocalized, in other words, disconnected from its geographical origins and the climatic constraints traditionally associated with them". In the face of growing complexity, it has then increasingly become the role of third parties to identify risks and guarantee product safety through a range of quality labels (Figuié and Bricas 2010). Despite regulatory bodies' function to provide highly controlled food production and trade, they may as well be contradictory or malfunctioning, resulting in mistrust (Inglis and Gimlin 2009, 19f). Also the role of science in food technology has become subject to growing scepticism as polarised public debates on genetically modified organisms (GMOs) exemplify (Wilk 2009; Poulain 2017, 68). On the international scene, such problems of industrial farming and manufacturing in the late 1970s became more and more apparent and were criticised, for example, by emerging environmental und feminist movements (Agarwal 1992; Moeckli and Braun 2001; McMichael 2012, 182ff.; Harcourt and Nelson 2015; Poulain 
$2017,66)$. The demand for more transparency, the call on governmental and other regulatory mechanisms, and the enforcement of consumer citizenship rights (Brooks et al. 2013) started to address the perceived need to re-embed the externalities of living in a 'risk society' in which scientific progress and knowledge not only provided solutions and probabilities for rational management of food scares but also permanently unleashed new incalculable risks (Beck 1992). Meanwhile, neoliberal policy on a global scale led to the birth of 'the consumer' — understood as an individual supposedly acting in the commoditised system of food provision on the basis of individual choice, total information, and personal utility-and, by consequence, to the individualisation of healthy and safe food choice (Parsons 2015).

In Vietnam, concerns over the safety of food have mounted with people being anxious about the effects of feeding their bodies with harmful food. Thus, while economic growth and gains in food productivity have meant a reduction in the prevalence of undernourishment in the country (Marzin and Michaud 2016), one now increasingly finds widespread concerns over food safety related to the harmful effects of the overuse of agricultural inputs as well as regarding the insufficient traceability of food. Correspondingly, consumers at times assess that while the variety of meals has improved, the quality of food products has diminished as has the trust in food regulation bodies to detect substandard produce (see Figuié et al., this volume). Faced with an emerging commoditised food system, the 'invention' of the consumer in Vietnam in recent decades coincided with described neoliberal economic paradigms on the international scene, standing in stark contrast to the prior governmental food rationing system and general discouragement of conspicuous consumption of foreign goods (Vann 2005, 468).

With the general surplus that emanated from industrial production in many world regions and "the majority of the populace hav[ing] access to the ever-growing consumerist fruits of the productivist tree" (Corrigan 2011,1 ), food consumption gradually became key for social differentiation as well as for food scholars engaging with food-related identities symbolically as well as in terms of its material conditions (e.g. Goody 1982; Klein 2014). 'Consumer culture', 'consumer society', and 'lifestyle' became common conceptual foci through which scholars aimed to 
describe central organising principles of social reality and identity. This focus breaks with class and occupation as the paramount lens to understand social inequality and change (Warde 1997, 7ff). Whereas some attest that the major goal of consumption lies in the expression of selfidentity (e.g. Bauman 1988), others understand lifestyles as part of a social class' habitus (e.g. Bourdieu 1984). Again others see lifestyle not as a coherent function of identity but rather in terms of fluid and conflictive plural lifestyles in post-modernist consumer culture (e.g. Featherstone 1990). ${ }^{10}$ Global agri-food industries and leisure economies in manifold shapes provide services, products, and imaginaries through which to express social belonging and demarcation. In this regard, the role of transnational companies inspired controversial studies on food globalisation conceptualised in terms of processes leading either to culinary and cultural homogenisation (e.g. Ritzer 1993) or to the localisation of global food consumerism creating culinary heterogeneities (e.g. Watson 1997). ${ }^{11}$ Often seen as symbols of US-American cultural imperialism and a threat to cultural peculiarities, such transnational brands are at times met with protest and hostility (Wilk 2009).

When following the workings of 'Big Food' monopolising complete global food chains, as discussed earlier, it does not come with surprise that respective food businesses eventually moved on from saturated markets in the Global North to emerging market-terrain such as Vietnam and other Southeast Asian countries. Western-style formats of fast food restaurants and coffee houses tend to appeal, for example, to Asian middle classes and become locally adapted as spaces for leisure and recreation, as family events or as spaces for business opportunities (Higgins 2008; King et al. 2008; Yan 2008; Earl 2014; Ehlert 2016).

Whereas for decades Vietnam was driven by the concern of providing adequate amounts of food, the symbolic meaning of food has come more and more into focus. This transformation in society's relation with food from scarcity to the increasing relevance of consumerism is also expressed in the Vietnamese proverb 'com no, áo âm; com ngon, áo dẹp'_-enough food and warm clothing; delicious food and beautiful clothing" (Ehlert 2016, 71). Questions of access to the material and symbolic quality of foodstuff options turns food into an ever-growing marker for social differentiation, inclusion, and exclusion in the context of rising standards of 
living, newly emerging middle classes, and related growth of socioeconomic disparities (Taylor 2004, xi; Van Nguyen-Marshall et al. 2012; Earl 2014). Growing prosperity also stands in relation to the country's nutrition transition which is characterised by a general increased calorie intake and growing shares of animal products, sugar, and processed foods in people's diets (Baker and Friel 2014). In contrast to the earlier times of shortages, Vietnam nowadays suffers from the so-called double burden of malnutrition (Walls et al. 2009; Vietnam Ministry of Health 2012; see also Sobal 1999, 178): cases of underweight prevail (Nguyen Cong Khan and Ha Huy Khoi 2008), while at the same time diet-related diseases of affluence such as obesity and heart-related diseases are on the rise (Avieli 2014). In this regard a strong divide between rural and urban areas can be observed with aspirational food-related lifestyles as well as overweight predominantly being phenomena of the cities (TQ Cuong et al. 2007) and child malnutrition often being a rural phenomenon (Nguyen Cong Khan and Ha Huy Khoi 2008). What Featherstone (1991), for example, accredits to a sheer overwhelming range of dietary, slimming, and other 'body-work' products on the shelves of supermarkets in the Global North, proliferated through advertisements, the popular press, and motion pictures can, without doubt, also be found in (urban) Vietnam. Drummond (2004) for instance describes the social construction of the Vietnamese woman in popular women's magazines. Miss Coca-Cola beauty contests in Hanoi and HCMC start to put female body work on public display (Drummond and Rydstrøm 2004, 12) and with the emergence of the urban fitness sector in the late 1990s, exercising has become a symbolic and physical expression of a modern lifestyle for (women of) the urban middle classes (Leshkowich 2012). What can be observed in urban Vietnam is the growing significance of the body being discursively turned into a gendered consumer object and that proliferates as prime 'locus' of self-discipline (see Ehlert, this volume).

As one can see, there is a lively debate going on in terms of bringing together consumption with different forms of identity construction that ranges from the extremes of the liberal idea of the freedom of choice to being an irreversible corollary of the socio-political context and the material conditions one lives in. The growing divide between insufficient access to (quality) food for some and oversupply of food for others makes 
Vietnam particularly vital for the study of food anxieties since people more and more have to manoeuvre between certain paradoxes: in the midst of growing food abundance, they, by eating, manoeuvre between health and illness, pleasure and displeasure (Beardsworth and Keil 1997), and social belonging and exclusion (Bourdieu 1984). In the Vietnamese context of neoliberal market transformation and rampant consumerism (Schwenkel and Leshkowich 2012), fast developing urbanisation, the modernisation of the agricultural and food industries as well as the emergence of certain health, beauty, and lifestyle trends, consumers are thus increasingly confronted with the insecurity of what they symbolically and physiologically ingest via their food options and deprivations. In contrast to the dominant definition of 'the consumer' described as driven by preferences, freedom of choice, and free information in neoclassical economics, the following book contributions all work on contextualisation (Kjærnes et al. 2007), namely on the socio-cultural processes and the structural power that the consumption and production of food and related social anxieties in urban Vietnam is embedded in.

\section{The Transgressive Nature of Food: Conceptualising Food Anxiety}

What is on one's plate (or not) is by many means complex given the transgressive nature of food. Goodman and Sage establish that for the human body "there are few things more essentially transgressive and boundarycrossing than food" $(2014,1)$. In the widest sense of the term, 'transgression'-being an established concept in social theory-refers to the delineation, crossing, and exceeding of spatial, discursive, behavioural, and material boundaries (Jenks 2003). We understand such boundaries as fluid 'areas' marked by relational interaction between blurred rather than supposedly clear-cut categories (Lamont and Molnár 2002).

The complexity of food then lies in its characteristic of bounding diverse scales in one's own mouth. Through the lens of food one can connect the past with the present, the individual with society and the domestic household with the world economy (Belasco 2007, 5). Yet, the complexity of food does not end on the plate. It is rather nurtured again 
by the very act of incorporation of food into the body (e.g. Fischler 1988, 279; Probyn 2000; Carolan 2011; Abbots and Lavis 2013; Lavin 2013; Abbots 2017). Eating thus constitutes the intersection of the body and the 'Self' (see Lupton 1996) or the 'objectified' and the 'lived' body (Gugutzer 2012). Correspondingly, the body is more than an object regulated by social norms and structural relations but constitutes the immediate site of the visceral and sensory experience of 'being-in-the-world' (Csordas 1990).

We, the editors, conceptualise food anxiety as evolving from transgressing diverse scales that lace the visceral being of the self with societal norms, political dynamics, and economic structures. The constant negotiation of such boundaries provokes essential questions, even poses threats, to relational integrity at different levels (Lavin 2013, xii). These internalised or unconscious as well as conscious negotiation processes are also captured through the concept of food neophilia and neophobiathe openness/affection towards respectively the distrust/fear of new food (Rozin 1976; Fischler 1988; Wilk 2009). Related to the 'omnivore's paradox', humankind's relationship to food is inherently contradictory, alternating between the search for diversification and mistrust of potential danger (Fischler 1988). In contrast to the terms 'uncertainty' or 'fear', which are rather confined to risks regarding food quantity, quality, and palatability, 'anxiety' captures more fundamental struggles over identity, difference, and power (Hayes-Conroy and Hayes-Conroy 2008). 'Anxiety' reflects not only on questions of integrity in terms of material 'realities' but also regarding the transgression of discursive structures. What one consumes and produces, can access or is excluded from tells something about one's class-based, gendered, racialised, and historical embeddedness in global capitalist systems of food production, distribution, and consumption. Furthermore, what one eats or refrains from needs to be seen in the context of diverse local social norms and taboos of food provisioning and responsibility (DeVault 1994) as well as understood as embedded in codes of body conduct, attractiveness (Lupton 1996; Probyn 2000; Cairns and Johnston 2015), and productivity (e.g. Foucault 1977, 1978; Featherstone 1991). Historical trajectories of food scarcity, emotions, and memories of food desire as well as imaginaries of abundance are imparted over generations (Sutton 2001). As such, food 
demarcates as well as crosses physical, symbolic, and imagined boundaries, and as the process of incorporation is so closely linked with subjectivity, it constitutes a great source of anxiety and risk in general (Lupton 1996, 16). Food anxiety in its symbolic and material dimensions, then, emerges as an effect of fundamental social processes and structures bound in relationality and the essential process of boundaries constantly being made and unmade (Lamont and Molnár 2002; Jenks 2003).

In the following presentation of the book structure, the reader will be introduced to the various dimensions of food anxiety as resonating at different intersections at stake. The editors' lens of food anxiety on the case studies will reflect on how and which boundaries are transgressed, negotiated, kept elastic, or reinforced. The book is organised in three parts, reflecting on different boundary crossings and respective food anxiety facets. Part I focuses on bodily transgressions and questions of (colonial) identity, gender, and power. Part II puts centre stage the boundaries between the supposed fixed triangle of state, market, and society by discussing questions of trust, responsibilisation, and coping regarding food safety. The final Part III turns to the politics of food security by elaborating on transgressions of territorial agricultural boundaries and volatile global food markets.

\section{Part I-Bodily Transgressions: Identity, Othering, and Self}

Part I of this book makes central the interface of the eating body, the subjective self and broader society. It discusses identity construction as a process strongly mediated through food consumption, deprivation, and body work. Eating offers insights into the ways in which identity, difference, and power are inscribed upon the body be it as formulated, for example, in Bourdieu's concept of the class-based habitus (1984) or by Foucault's techniques of self-discipline and optimisation (1988; Parsons 2015), as socialised into gendered bodies (Butler 1993; Lupton 1996) or as racialised 'Others' (Hall 1997; Slocum and Saldanha 2013). Furthermore, the focus on eating throws light on agency and the "micropractices of contestation and acceptance" (Abbots 2017, 14) towards 
the structural, discursive, and material forces working on the body. Embodiment - as the sensory, visceral, and emotional dimensions of bodies as 'being-in-the-world' (Csordas 1990)_draws attention to the very sensual experiences of being regulated in terms of gender, class, and race but also to embodiment as a potential site of resistance (Abbots 2017, 20f.).

Eating as a project of negotiating identity is fundamental. The positioning vis-à-vis 'foreign' food either through hostility or openness can be an expression of a perceived threat towards an imagined culinary origin as much as the demonstrated consumption of the unfamiliar can be an expression of distinction or sophistication (Wilk 2009; see Peters, this volume). As we will see with the first contribution by Erica J. Peters, this colonial power play very subtly materialised in people's everyday foodways. Peters's chapter 'Power Struggles and Social Positioning: Culinary Appropriation and Anxiety in Colonial Vietnam' opens this section by providing an in-depth historical portray of food-related anxieties as rooted in different power constellations. By focusing on Vietnam's precolonial and colonial culinary history, Peters lays the groundwork for the subsequent book chapters which concentrate primarily on food anxieties in contemporary Vietnam. The choice to integrate a historical perspective in this volume was made in order to avoid assumptions about the historical singularity of phenomena (Inglis and Gimlin 2009, 11). Peters's historical account elaborates on the central point of food becoming a powerful vehicle to rise in and to demarcate one's social status as well as to exclude others from social mobility. The chapter deals with anxiety on the part of the colonial power(s) in Vietnam. Anxiety here is triggered by colonised bodies incorporating French foods. French colonisers perceived the Vietnamese elite and general population eating French food according to French etiquette as acts of bodily and symbolic transgressions by the 'uncivilised'. To the contrary, the Vietnamese colonial elite actually played with such dichotomies of the 'civilised' and the 'backwards' by displaying the sophistication of their own food etiquette and gustatory traditions. Through demonstrations of the French's inability to handle, for example, chopsticks, the Vietnamese relativised narratives of 'civilisation' and, therewith, turned the embodiment of Vietnamese food into a potential site of resistance towards the colonial regime. Besides 
examining food anxieties during the French colonisation of Indochina both on the side of the colonisers and on the colonised society, Peters also takes a look at intra-societal conflicts and anxieties along the lines of class, location, and political views. She uses food as a lens to show how the complex social boundaries, for example, between the rural 'backwards' and the local (urban) elite, were constantly transgressed, reinforced, reproduced, and challenged along matrixes of constructed 'superiority' and 'inferiority'. Peters's contribution shows the intimate relationship between food and claims of social and political authority as a means to assure oneself and one's own identity against the respective Other. She closes with the argument that anxiety evolves on the part of the colonisers because their power feels illegitimate and vulnerable more generally. This would make the constructed demarcation line between the refined 'culinarily civilised' and the 'rawness' of the colonised bodies becoming more and more porous.

Whereas anxiety in Peters's chapter is triggered by supposedly clear-cut identities of the powerful and the subordinate becoming transgressed through food practices, the subsequent chapter by Nir Avieli relates to anxiety as a matter of transgressing food taboos and social norms of food restrictions. In his chapter 'Forbidden from the Heart: Flexible Food Taboos, Ambiguous Culinary Transgressions, and Cultural Intimacy in Hoi An, Vietnam' Avieli brings the reader's attention to contemporary Vietnam and presents an ethnographic study conducted in the central Vietnamese town of Hoi An. Avieli's ethnography zooms into the catering and consumption of he-goat meat and 'jungle' meat, both subject to certain food taboos. He describes the food venues where these 'forbidden' meats are served as strongly marked by the symbolic display of extreme masculinity, characterised by both vague and blatant associations with sexual services and female suppression as well as the abuse of political and social power. In the two case studies and along the cultural symbolism of meat, the essence of the patriarchal system of dominance and power as in men over women and men over animals and nature unfolds through the incorporation of the female sexualised Other and of 'forbidden' meats (Twigg 1983; Adams 2000; see also Probyn 2000). Another momentum of masculine 'might' shows in the abuse of the law through the incorporation of the 'wild' flesh of legally protected forest animals. The dense 
atmospheric description of respective food venues imparts to the reader the strong ambivalence that accompanies the consumption of such symbolically contaminated meats (Rozin 1976). Avieli tickles out the conflictive affair of eating between lust and disgust. Being aware that their culinary practice is ambivalent as it transgresses social and moral imperatives, the eaters of tabooed meat escape to what he describes with Herzfeld as 'cultural intimacy' (Herzfeld 2005). This notion constitutes that the act of transgression itself creates new boundaries of social bonding in these arbitrary culinary places. There, cultural intimacy becomes based on essentialised maleness through the subordination and symbolic consumption of the female and the wild. The transgression of such food taboos loaded with gendered notions of masculinity and femininity becomes even reinforced by social condemnation. Thus, the chapter illustrates the relationality of boundaries at play with the discussed meats being subject to taboos and anxiety in some and desirable and identityinstilling in other contexts.

Part I closes with a chapter by Judith Ehlert titled 'Obesity, Biopower, and Embodiment of Caring: Foodwork and Maternal Ambivalences in Ho Chi Minh City'. According to the World Health Organisation, obesity constitutes one of the major food anxieties as the threat it poses is global in scale. It is supposed to put public health systems as well as the productive labour force of whole economies under pressure (WHO 2000). In this vein, fatness is considered a moral transgression and obese people conceived as supposedly unable to restrain themselves for the public good and in the name of idealised personal responsibility (LeBesco 2011; Lupton 2013; Cairns and Johnston 2015, 89ff.). For the first time in recent history following the opening-up of the economy, obesity and being overweight have also entered the public health discourse in Vietnam relating it to general dietary changes towards the increasing consumption of processed, convenience, and high-calorie foods (Vietnam Ministry of Health 2012). The government addresses the global 'obesity epidemic'12 through national programmes on nutrition and health education and public awareness campaigns. The obesity discourse and the media's and the food industry's diverging appeals of 'consume and abstain' serve the author as a scaffold for her empirical study on how mothers experience the conflicting social norms and practices of feeding children amidst the 
prescription of certain body and beauty ideals for children. She elaborates how food femininities are constructed through discourses and practices of mothering and rooted in the embodiment of caring for oneself and one's children. Ehlert argues that food anxiety on the side of mothers and mothers-to-be arises from the conflicting demands being placed on them. First, a whole food industry co-opts the practice of feeding and caring as it promotes their products tainted with paramount symbols of love and care for profit-making purposes. Second, and simultaneously, public health campaigns urge mothers to regulate their children's unhealthy appetites, coupled with social media fora and lifestyle blogs pandering to 'modern' and responsible mothering. Third, intergenerational conflicts regarding the regulation of children's nutrition add to the complex demands that frame the 'correct' feeding of children as a mother's obligation and as essential to her 'moral personhood'. These conflicts materialise in certain ways to discipline the child's body and leads to mothers exerting self-discipline on their own bodies. The chapter shows that the correspondence with social norms addressing femininity and the child's body as object in terms of its shape and physical constitution are inevitably internalised as well as embodied in the phenomenological sense (Crossley 2012). The conflicting demands of caring become embodied and arouse sensual ambivalences wielding socially structured food anxiety.

\section{Part II-Food Safety: Trust, Responsibilisation, and Coping}

By addressing food safety, the contributions in the second section touch upon an aspect of food anxiety of high societal relevance and one of the most prevailing contemporary food concerns in Vietnam. The empirical basis of this section counters the academic bias that discusses concerns for food quality and safety predominantly as phenomena of the Global North. Against the structural framework of the capitalist system of food production and provision, Part II deals with subjective feelings and discourses on food anxiety that actors experience in the face of decreasing transparency in global food chains that reaches down to local urban 
markets. Moreover, this section centres on the relational power between society, state, and the market in terms of food safety as it articulates questions of how people negotiate the described intransparency and lack of accountability when eating food that is perceived as hazardous. Related to the previously mentioned sweeping changes in food provisioning are transformations in qualification processes of food. Whereas in wet markets quality is observed directly and sensorily on the basis of embodied food knowledge, in supermarkets third-party labels on often pre-packaged foods are supposed to be quality guarantors (Figuié and Bricas 2010, 187). Concomitantly, trust is negotiated very differently in the face of third-party institutions. At the same time the relation between state and society has seen a change in character: while under central planning consumerism was officially frowned upon and possible mostly on an illicit black market, post Đổi Mới citizens are expected to embody their roles as consumers (Vann 2005). And while structurally the government continues to exercise power over the conditions of the food system, its role is now more indirect in terms of decision-making. Rather, policy interventions and market paradigms position the individual as responsible for behavioural change regarding (food) shopping based on the execution of choice (Wertheim-Heck 2015). As stated, it is particularly anxieties that touch on the safety of food that are examined under Part II. Besides issues of food hygiene, it is especially the question of chemical contamination that concerns people regarding their health and bodily integrity. Through mismanagement of (at times illegal) agricultural inputs, preservatives in food processing and chemicals used in food scams, unclear amounts and types of substances make their way into food and eventually into people's bodies. To a certain degree, people are 'blindfolded' when eating as they cannot retrace the origin and the quality of the food they ingest on a daily basis, stirring people's insecurity in terms of harming one's health and bodies. ${ }^{13}$

This second part begins with the chapter 'Trust and Food Modernity in Vietnam' by Muriel Figuié, Paule Moustier, Nicolas Bricas, and Nguyen Thi Tan Loc, and provides an overview of the food safety concerns that exist in current-day Vietnam. This contribution presents empirical research into Vietnam's transforming food system and the anxieties associated with this. By specifically drawing on the notion of trust 
in consumers' search for quality food, this chapter examines people's strategies of coping with a food system in transition. It builds on the idea that there exist three types of food systems - traditional food systems, modern food systems, and late modernity systems - with very different risks as well as qualification processes of food. Due to the speed of changes in terms of industrialisation, urbanisation, and economic liberalisation in recent decades, the authors hypothesise that the food system in Vietnam shows characteristics of all three types of food systems as it has been transformed by a 'compressed modernity'. Traditional food systems are characterised by small-scale farming as well as small local markets where food quality is assessed directly through the senses and based on trust in familiar sellers. In the face of industrialised food production and lengthened food chains in modern food systems, then, the gap between a highly specialised food sector and the population not involved in food production is bridged by institutions who guarantee the quality of food through formalised labels. As such a liberalised food system produces sustainability and safety issues that cannot be assessed by consumers directly and thus are less acceptable to them, the authors then speak of food systems of late modernity in which the negative consequences behind the achievements of modernisation such as productivity increases become visible. It is under these intransparent and complex circumstances that food safety becomes a major concern of consumers since neither direct qualification nor governmental controls seem to be able to offer sufficient trust in food. Consequently, consumers diversify their ways of building trust in food sources and navigate between them depending on the context. Figuié et al. describe how the boundaries between the different and coexisting systems are at times fluid and how they are negotiated by consumers while posing a source of anxiety at the same time. The exceptionally rich empirical basis for this chapter composes data from 12 years of research in Vietnam. By conceptually marrying questions of trust with modernisation processes of the food system, the chapter offers insights into the sources of and dealings with currentday food anxieties in Vietnam.

The following chapter 'Between Food Safety Concerns and Responsibilisation: Organic Food Consumption in Ho Chi Minh City' by Nora Katharina Faltmann focuses on one specific response to food 
anxieties in the form of eating organically produced food. This chapter examines emerging organic food consumption in urban Vietnam and contextualises it within the country's current food safety situation. Faltmann's empirical research on Ho Chi Minh City indicates that while environmental concerns do not play a role in organic consumption, personal health concerns and food anxieties in light of the prevailing food safety issues do all the more so. With this, consumers' individual motivations for buying organic products in urban Vietnam differ widely from the emergence of organic food consumption as part of wider environmental movements in the Global North that still often informs Westerncentric understandings of organic consumption. The chapter points out that whereas organic sectors in Global North contexts have seen strong corporatisation and conventionalisation tendencies in past decades, environmental protection continues to serve as the official rationale behind many foreign-financed organic initiatives in Vietnam. Yet in the context of the country's food safety issues, Vietnamese consumers rather seek organic food as an individual response to food safety concerns, particularly in terms of chemical contamination. With the clientele of Ho Chi Minh City's high-priced organic niche market most prominently being highly educated, well-earning, and female in familial care positions, organic food consumption is moreover structured along the lines of class and gender. Opting for organic food, thus, poses an individual strategy to achieve safe food provisioning for oneself or one's family within the realms of market logic. Similarly, the chapter identifies the recent growing interest of the Vietnamese state in the development of the organic sector as clearly corporate-driven whereas the governmental emphasis on productivity-oriented agriculture and overall food security persists. The at times contradicting influences of neoliberal consumer discourse, the socialist state as well as contemporary food safety issues simultaneously structure the organic sector and produce food anxieties that Faltmann illustrates based on the narratives of organic food consumers. It is in this vein that the author embeds her findings on organic consumption within changing societal discourses that mark a shift in the relations between the government, the market, and the individual.

Notions of what constitutes safe food and ways to acquire such are also an element of the next chapter, this time with a focus on (informal) 
practices of urban gardening in Hanoi. In this chapter, Sandra Kurfürst links her own empirical research on urban gardening practices and ruralurban food supply in Vietnam's capital with conceptions of the rural and the urban. 'Urban Gardening and Rural-Urban Supply Chains: Reassessing Images of the Urban and the Rural in Northern Vietnam' argues that while binary categories of the rural and the urban in Vietnam persist in imaginaries, the boundaries between them are oftentimes transgressed in practices of everyday life. The author recalls the symbolic meanings of the urban as a hub of modernity, political power yet also as polluted and disorderly in contrast to the countryside which is regarded as a socially intact place of tradition, in touch with nature and source of safe and fresh food, yet also designated as potentially backward. These binary categories are continuously reproduced in social interaction while at the same time being resolved in everyday practices (in the city). These practices are then worked out by Kurfürst in relation to prevailing food anxieties and urbanites' quest for safe and fresh food. Through, for example, growing food in urban space on sacred pagoda land, in private spaces prior dedicated to ornamental rather than edible plants or in public spaces, ideas of what constitutes inherently urban or rural practices and spaces are negotiated. In the case of gardening on public land in Hanoi that the government increasingly transforms from agricultural to construction land, citizens — so the author argues_-make (subversive) usage of space purposed for economic activities, hence actively shaping their urban environment. With such interim usage often being tolerated by local authorities, 'mediation spaces' occur in which the boundaries between public and private, economic and agrarian, are re-negotiated and fluid while on a national level, policies for the re-zoning of agricultural land into investment land for development projects (see Gorman, this volume) intend more clear-cut determinations of the functions and value of land through concomitant classifications. Another realm that expresses fluidity between rural and urban conceptions in Vietnam's urbanising society lies in relations urbanites maintain with kin in their rural place of origin. The source of knowledge for cultivating food in the city often lies in the rural biographies of urban gardeners. Moreover, such rural-urban ties also function as provision systems for urban residents with food from the countryside. Other than food from 
the in-between spaces of vast peri-urban areas providing Hanoi with food, products directly from the countryside are trusted as safe and fresh. This applies all the more so if this food is acquired through direct personal relations even though the end consumers might know little about the conditions of production or origin. Thus, the chapter shows that on the one hand the rural/urban binary continues to inform the way people imagine space as well as safe food, while on the other hand their practices often prove the fluidity and ambivalence of such imagined boundaries.

\section{Part III-The Politics of Food Security}

Part III touches on the most basic anxiety around food: food securitynamely the adequate availability and accessibility of food not only to meaningfully fuel one's body but to avoid malnutrition and chronic hunger. At the 1996 World Food Summit in Rome, food security was defined as "exist[ing] when all people, at all times, have physical and economic access to sufficient, safe and nutritious food that meets their dietary needs and food preferences for an active and healthy life" (FAO 1996). Critical debates on food security often take a swipe at the concept's apolitical core and its technocratic understanding of 'feeding the world' from the topdown (Holt Giménez and Shattuck 2011). The genuine political nature of food safety, however, comes into light when relating it more closely to the path-dependency of colonial exploitation, the unequal conditions of global trade, and mass production and mass consumerism bearing most severely on marginalised groups to cater for their food needs. The political dimension of food security also plays in as much as food provision and accessibility are crucial in terms of national sovereignty and political authority, providing the essential backbone for a regime's legitimacy (Bohstedt 2016).

Part III of this book centres on such political dimensions of food security when it discusses questions of national sovereignty and the limits of protecting domestic production markets amidst global food provisioning systems. The chapters in this book part portray how, despite the general abundance of food on a global scale and increase in consumer affluence, structural deficiencies of the agri-food system continue to work to the 
detriment of marginalised groups. Food security as a basic need seemed almost forgotten in Vietnam, tranquilised as it was by the heydays of economic growth and agricultural boom. On the basis of its agricultural output records in recent decades, Vietnam not only provides for the domestic market but contributes significantly to the global food provisioning system through its agricultural export orientation. However, the global food crisis that reached fever pitch in 2007/2008 exposed Vietnam's shaky interconnectedness with volatile agricultural commodity markets. Although much less than elsewhere, when the food crisis hit Vietnam it sharply called the assumed steadfastness of food security into question. As will be shown, China plays a dominant role for the development and future of the Vietnamese agricultural sector. Besides the relationality of the food security strategies of both countries, they are strongly connected in terms of food safety issues. What will become most apparent in the two chapters in Part III is the class-based dimension of having enough (safe) food to eat-no matter on which side of the national borders one is. The permeability of both national agricultural sectors towards global agri-food trends is highlighted by the following chapters whereas food anxiety will show in reinforcing class-based boundaries. This is what will be focussed as the politics of food security in this book part.

In his chapter 'From Food Crisis to Agrarian Crisis? Food Security Strategy and Rural Livelihoods in Vietnam', Timothy Gorman begins with a scene of food panic that economic analysts would not have dared to suspect; as the food price crisis of 2007/2008 swept Vietnam, anxious consumers queued up to buy food and hoarded supplies of rice. As one economist exclaimed in disbelief: "In Ho Chi Minh City, for heaven's sake, the centre of the second-largest rice exporting surplus in the world, supermarkets and rice markets got cleaned out in two days" (Timmer in Charles 2011). Gorman takes this alarming outcry as basis for his meticulous inspection of the post-crisis national food security strategy as defined in Resolution 63. His discourse analysis brings to light the specific cultural, political, and historical pathway that the document was formulated on and the government's priority to shield the Vietnamese population from falling back into historical times of rice insecurity. Whereas panic buying of urban consumers in 2007 constitutes the starting point for Gorman to illustrate the reactions to the global food crisis 
in Vietnam, in his chapter, he reconstructs the rationale of why the government responded in the way it did. According to him, the legacy of food shortages in Vietnam translates into the historical promotion of production- and supply-oriented rice agriculture as a means to prevent political unrest throughout the different times and regimes (see also Peters, this volume). In connection with this, the chapter discusses Confucianist norms of sovereignty, based on the teleological power of the sovereign to provide for its people, the deeply entrenched symbolism of rice for the Vietnamese diet and identity as well as rice constituting the major foodstuff for the rural poor and urban working classes as crucial drivers of the post-crisis rice policy. The chapter then brings together the implementation measures of Resolution 63 with a broader agrarian crisis. In his case study, the author discusses how the resolution has affected the social conditions and peasants' class struggles more broadly in the ricegrowing areas in the Mekong Delta. Gorman summarises the externalities of the modernised and production-oriented rice and food policy by describing a 'general air of agrarian crisis in the countryside'. This 'general air' on the part of small-scale peasants speaks of their anxiety regarding the insecure and blurry options they have when dropping out from the agricultural sector with not too many options for being meaningfully absorbed by other economic sectors. With his chapter and from the standpoint of critical agrarian studies, Gorman retraces food-relationality between various scales - from the volatile bubble of global trade markets to the territorially bounded nation-state aiming to provide food security down to the risky livelihoods of small-scale farmers in the Mekong Delta. This implies food, in this case rice, to travel between the boundaries of highly abstract food markets, over fairly concrete physical and territorial boundaries to the embodied boundaries of food producers and consumers alike. Furthermore, this chapter covers the historical interconnectedness of time-related boundaries when it brings together the collective memory of food scarcity of the past that carries on as an imperative for the party's resolution to provide food in a self-sufficient and production-oriented manner within own territorial boundaries.

In his chapter 'When Food Crosses Borders: Paradigm Shifts in China's Food Sectors and Implications for Vietnam', Hongzhou Zhang assumes that it would be politically, diplomatically, and practically challenging for 
Vietnam to repeat the ban of rice exports, as was done in 2007/2008, in the case of another crisis. With China being the biggest rice consumer in the world and Vietnam supplying an enormous share, Zhang analyses the implications of China's overall food security strategy and changing consumer food preferences for the Vietnamese agri-food market and for global agricultural developments more broadly. Due to its growing production gap China turns to alternative measures to assure growing domestic demand and national food security in staples. As in Vietnam's agricultural policy (see Gorman, this volume), China also prioritises farmland concentration to the dead end of small-scale agriculturalists. Besides further exploitation of the aquatic and marine resources which has recently triggered a lot of geopolitical conflict between Vietnam and China, China heavily invests in agricultural technology developments in the form of GMOs. This is backed by China's economically powerful merger and acquisitions of business giants in the agri- and pharmaceutical sectors which are likely to shape the GMO agenda for the global agrifood industry as a whole (Zhang 2016). In the same vein, China's agriculture going global relies on land-based investments outside of its national territory - a strategy often criticised as neocolonial land grabbing (Hofman and Ho 2012). Zhang then zooms in on domestic food consumption leading the focus to food safety issues in China as well as beyond its borders in Vietnam. Part II of this book on food safety portrays Vietnamese consumers being suspicious towards the consumption of Chinese food produce. Given Vietnam's suspicion towards the 'Big Brother China', the ambivalences arising in Vietnam are twofold: on the one hand, the Vietnamese discourse condemns Chinese food ${ }^{14}$ as it is perceived harmful for a person's health as well as for national integrity more generally; on the other hand though, the relative affordability of Chinese imported produce caters to a substantial demand for cheap food of the working class and destitute groups in urban and rural society in Vietnam. Zhang's data shows that counterfeit and substandard food products legally and illegally entered the Vietnamese consumer market. Furthermore, China's increasingly harsher environmental policies drive Chinese low-end food manufacturing, fertiliser, and pesticide sectors out of the domestic market, which resettle in emerging markets like Vietnam. Just like for the Vietnamese case, broader changes in dietary patterns in 
China expose strong class-based differences and rural-urban divides. Whereas high- and middle-income consumers turn to (partly organic) imports from neighbouring Southeast Asian countries which are perceived as safer, consumers who cannot afford to go the safe way suffer from sharply rising domestic retail prices and substandard food supply to the detriment of their health. Evidently, food anxiety for price-sensitive consumers on both sides of the border in China and Vietnam relate to food security as well as food safety concerns. The food legally and illegally traded in both directions of the national borders show how food risk is passed on domestically and across the land borders to poorer groups who structurally make up the major 'recipients' of such food risks endemic to the domestic as well as global food systems.

\section{Notes}

1. For an overview, see Mintz and Du Bois 2002; on Vietnam, see Avieli 2012.

2. We thank Carina Maier for providing us with this photo as it captures the essence of this book so well.

3. By approaching food as a paramount physical and social requirement of human existence, it was anthropological and sociological scholars in particular who lifted food out of its perceived irrelevance for scientific discovery (e.g. Lévy-Strauss 1997; Mintz 1985; Mintz and Du Bois 2002; Murcott 1983; Mennell et al. 1992; Counihan and Kaplan 1998; Poulain 2017).

4. For detailed works engaging with food anxiety theoretically and empirically see, for example, Abbots 2017; Jackson 2015; Lavin 2013.

5. For an example on an intersectional approach to issues of food access in the USA, see Alkon and Agyeman 2011.

6. Of course, Vietnam's colonial history pre-dates the arrival of the French colonial regime as much as the formation of the nation-state itself involved the forced subordination of diverse ethnic groups by the ethnic Vietnamese (Kinh) majority in the pursuit of arable land to fight hunger in scarcity-prone areas (see Peters, this volume). Since ethnic Vietnamese (Kinh) gained rule over Chinese power in $939 \mathrm{AD}$ and claimed rule in the Red River Delta in the North (Bắc Bộ), the Vietnamese "slowly inched their way through the centre (Trung Bộ) into the South (Nam 
Bộ), opening new land to colonisation and encouraging migration from older areas" (Popkin 1979, 84). During the great "advance to the south" (Nam tiến) (Hickey 1967, 2) first Vietnamese and Chinese settlers reached the Mekong Delta in the 1600s (see Peters, this volume; Biggs 2004, 79; Brocheux 1995, 10ff.). This claim of new frontier land involved the forced colonisation of diverse ethnic populations in the areas defeated by the ethnic Vietnamese (Taylor 2007; Scott 2009) and marked the beginning of a decades-long internal food transfer from the southern delta for fighting hunger in the scarcity-prone regions (Biggs 2004; Brocheux 1995).

7. The French colonial terms for these regions were Cochinchina for the southern, Annam for the central, and Tonkin for the northern region.

8. Also known in the USA as the 'Vietnam War'.

9. At the peak of the crisis skyrocketing prices for staple food resulted in menacing levels of food insecurity and malnutrition and sparked protests and food riots in a number of countries in the Global South. Revealing the instability of the global food system through the volatility of world market prices, the crisis was caused by the interplay of a variety of shortterm factors including financial speculation in agricultural commodity markets, export restrictions, decreasing global grain stocks, and bad harvests. These were coupled with long-term shifts including land competition between crops for food and crops for livestock feed and so-called biofuels and rising fuel prices in fossil fuel dependent agrarian systems (Mittal 2009; Weis 2013).

10. For a summary of the debate, see Warde 1997.

11. Ritzer's work on the McDonaldisation of Society (1993) discusses rationalisation as a principal structural driving force of modernisation in general and in the field of food consumerism specifically, predicting a certain trend of culinary homogenisation. Watson (1997) confronted Ritzer's rather pessimistic outlook regarding the loss of culinary diversity. Along with empirical case studies on the localisation of fast food markets, Watson highlights that the structural expansion of McDonaldisation does not inevitably lead to cultural homogenisation but rather to the localization of this structural imperative-fostering global culinary heterogeneity.

12. For a critical perspective of the social construction of the 'obesity epidemic' in China, see Greenhalgh 2016; for a critical account of the 'obesity epidemic' and neoliberalism, see, for example, Guthman 2009 and Metzl and Kirkland 2010. 
13. The chapters in this section have set their primary focus on perceptions and practices of urban consumers, while food safety of course also relates to the realms of the rural. While (harmful) agricultural practices are part of the general food safety debate and academic focus, farmers' perspectives are often given less room despite their central role in and direct contact with food production. Whereas Part III of this volume zooms in on the major changes in domestic agriculture in the course of agricultural restructuring policies of the government, rural perspectives on issues of food safety are not part of this volume, posing one of its limitations. We certainly would have liked to integrate such work and are convinced that perspectives of rather than on those growing the food would deepen insights into the country's food safety debate and require further academic attention.

14. Suspicion towards the safety of Chinese food imports is not confined to Vietnam (for Japan, see Walravens 2013).

\section{References}

Abbots, E.-J., 2017. The Agency of Eating: Mediation, Food and the Body. Contemporary Food Studies: Economy, Culture and Politics. London; New York: Bloomsbury Academic.

Abbots, E.-J., Lavis, A. (eds.), 2013. Why We Eat, How We Eat: Contemporary

Encounters between Foods and Bodies. Farnham; Burlington: Ashgate (Critical Food Studies).

Adams, C. J., 2000. The Sexual Politics of Meat: A Feminist-Vegetarian Critical Theory. 10th anniversary ed. New York: Continuum.

Agarwal, B., 1992. The Gender and Environment Debate: Lessons from India. Feminist Studies 18(1), 119-158.

Akram-Lodhi, H. A. 2004. Are 'Landlords Taking back the Land'? An Essay on the Agrarian Transition in Vietnam. European Journal of Development Research 16(4), 757-789.

Akram-Lodhi, H. A. 2005. Land Markets and Rural Livelihoods in Vietnam. ISS/UNDP Land, Poverty and Public Action Policy Paper No. 4. The Hague: Institute of Social Sciences (ISS).

Alkon, A.H., Agyeman, J. (eds.), 2011. Cultivating food justice: race, class, and sustainability, Food, health, and the environment. Cambridge: MIT Press.

Avieli, N., 2012. Rice talks: food and community in a Vietnamese town. Indiana University Press, Bloomington. 
Avieli, N., 2014. Vegetarian Ethics and Politics in Late-Socialist Vietnam. In: Jung, Y. (ed.). Ethical eating in the postsocialist and socialist world. Berkeley: University of California Press, 144-166.

Baker, P., Friel, S., 2014. Processed foods and the nutrition transition: evidence from Asia: Processed foods and nutrition transition in Asia. Obesity Reviews 15(7), 564-577.

Bauman, Z., 1988. Freedom. Concepts in Social Sciences Series. California: University of Minnesota Press.

Beardsworth, A., Keil, T., 1997. Sociology on the menu: an invitation to the study of food and society. London; New York: Routledge.

Beck, U., 1992. From Industrial Society to the Risk Society: Questions of Survival, Social Structure and Ecological Enlightenment. Theory, Culture \& Society 9(1), 97-123.

Belasco, W. J., 2007. Appetite for change. How the counterculture took on the food industry. Ithaca: Cornell University Press.

Beresford, M., 2001. Vietnam: The transition from central planning. In: Rodan, G., Hewison, K. and Robison, R. (eds.). The political economy of Southeast Asia: conflict, crises and change. Melbourne: Oxford University Press, 206-233.

Beresford, M., 2008. Doi Moi in review: The challenges of building market socialism in Vietnam. Journal of Contemporary Asia 38(2), 221-243.

Biggs, D. A., 2004. Between the Rivers and Tides: A Hydraulic History of the Mekong Delta, 1820-1975. Ph.D.-Thesis, University of Washington.

Bohstedt, J., 2016. Food riots and the politics of provisions from early modern Europe and China to the food crisis of 2008. The Journal of Peasant Studies 43(5), 1035-1067.

Bourdieu, P., 1984. Distinction. A Social Critique of the Judgement of Taste. London: Routledge and Kegan Paul.

Bricas, N., 1993. Les caractéristiques et l'évolution de la consummation alimentaire dans les villes africaines. In: Muchnik, J. (ed.). Alimentation techniques et innovations dans les régions tropicales. Paris: L'Harmattan, 127-160.

Brocheux, P., 1995. The Mekong Delta: Ecology, Economy, and Revolution, 1860-1960. Madison: University of Wisconsin (Madison Monograph No. 12). Brooks, S., Watson, D. B., Draper, A., Goodman, M., Kvalvaag H., Wills W., 2013. Chewing on Choice. In: Abbots E.-J., Lavis, A. (eds.), 2013. Why We Eat, How We Eat: Contemporary Encounters between Foods and Bodies. Farnham; Burlington: Ashgate, 149-168 (Critical Food Studies).

Butler, J., 1993. Bodies That Matter: On the Discursive Limits of 'Sex'. New York: Routledge. 
Cairns, K., Johnston J., 2015. Food and Femininity. London; New York: Bloomsbury Publishing (Contemporary Food Studies: Economy, Culture and Politics).

Carolan, M. S. 2011. Embodied Food Politics. Farnham; Burlington: Ashgate (Critical Food Studies).

Charles, D., 2011. How Fear Drove World Rice Markets Insane. In: All Things Considered, National Public Radio.

Clapp J., Scrinis G., 2017. Big Food, Nutritionism, and Corporate Power. Globalizations 14(4), 578-595.

Corrigan, 2011. The Sociology of Consumption: An Introduction. London; Thousand Oaks: Sage Publications.

Counihan, C., Kaplan, S. L. (eds.), 1998. Food and Gender: Identity and Power. Food in history and culture. London: Routledge.

Crossley, N., 2012. Phenomenology and the Body. In: Turner, B.S. (ed.). Routledge Handbook of Body Studies. New York: Routledge, 130-143.

Csordas, T., 1990. Embodiment as a Paradigm in Anthropology. Ethos 18(1), $5-47$.

Dang Phong, 2004. Stages on the Road to Renovation of the Vietnamese Economy: A Historical Perspective. In: Beresford, M., Angie Ngoc Tran (eds.). Reaching for the Dream: Challenges of Sustainable Development in Vietnam. Copenhagen: NIAS Press (NIAS Studies in Asian Topics 33), 19-50.

DeVault, M. L. 1994. Feeding the Family: The Social Organization of Caring as Gendered Work. Chicago: University of Chicago Press (Women in Culture and Society).

Drummond, L. 2004. The Modern "Vietnamese Women": Socialization and Women's Magazines. In: Drummond, L., Rydstrøm, H. (eds.). Gender Practices in Contemporary Vietnam. Singapore: Singapore University Press, $158-178$.

Drummond, L., Rydstrøm, H. (eds.), 2004. Gender Practices in Contemporary Vietnam. Singapore: Singapore University Press.

Earl, C., 2014. Vietnam's New Middle Classes: Gender, Career, City. Copenhagen: NIAS Press (Gendering Asia 9).

Ehlert, J., 2012. Beautiful Floods. Environmental Knowledge and Agrarian Change in the Mekong Delta, Vietnam. Berlin: Lit.

Ehlert, J., 2016. Emerging consumerism and eating out in Ho Chi Minh City, Vietnam. The social embeddedness of food sharing. In: Sahakian, M., Saloma, C.A., Erkman, S. (eds.). Food Consumption in the City: Practices and patterns in urban Asia and the Pacific, Routledge studies in food, society and the environment. London; New York: Routledge, 71-89. 
Endres, K.W., 2013. Traders, markets, and the state in Vietnam: Anthropological perspectives. ASEAS - Austrian Journal of South-East Asian Studies 6(2), 356-365.

FAO - Food and Agriculture Organization of the United Nations, 1996. Rome

Declaration on World Food Security. Document adopted at the 1996 World Food Summit, http://www.fao.org/docrep/003/w3613e/w3613e00.htm, last accessed on 03.03.2018.

Featherstone, M., 1990. Perspectives on Consumer Culture. Sociology 24(1), 5-22.

Featherstone, M., 1991. Consumer Culture and Postmodernism. London: Sage. Figuié, M., Bricas, N., 2010. Purchasing Food in modern Vietnam: When supermarkets affect the senses. In: Kalekin-Fishman, D., Low, K.E.Y. (eds.). Asian Experiences in Every Day Life: Social Perspectives on the Senses. Burlington: Ashgate, 177-194.

Fischler, C., 1988. Food, self and identity. Social Science Information 27, 275-292.

Fortier, F., Tran Thi Thu Trang, 2013. Agricultural Modernization and Climate Change in Vietnam's Post-Socialist Transition. Development and Change 44(1), 81-99.

Foucault, M., 1977. Discipline and Punish: The Birth of the Prison. New York: Vintage Books.

Foucault, M., 1978. The History of Sexuality. New York: Vintage Books.

Foucault, M., 1988. Technologies of the Self. In: Martin, L. H., Gutman, H., and Hutton, P. H. (eds.). Technologies of the Self: A Seminar with Michel Foucault. London: Tavistock, 16-49.

Friedmann H., McMichael, P., 1989. Agriculture and the State System: The Rise and Decline of National Agricultures, 1870 to the present. Sociologia Ruralis 29(2), 93-117.

Goodman, M. K., Sage, C., 2014. Food Transgressions: Making Sense of Contemporary Food Politics. London; New York: Routledge (Critical Food Studies).

Goody, 1982. Cooking, Cuisine and Class: A Study in Comparative Sociology Cambridge: Cambridge University Press.

Greenhalgh, S., 2016. Neoliberal science, Chinese style: Making and managing the 'obesity epidemic'. Social Studies of Science 46(4), 485-510.

Gugutzer, R., 2012. Verkörperung des Sozialen. Neophänomenologische Grundlagen und soziologische Analysen. Bielefeld: Transcript.

Guthman, J., 2009. Teaching the Politics of Obesity: Insights into Neoliberal Embodiment and Contemporary Biopolitics. Antipode 41(5), 1110-1133. 
Hai Thi Hong Nguyen, Wood, S., Wrigley, N. 2013. The emerging food retail structure of Vietnam. Phases of expansion in a post-socialist environment. International Journal of Retail \& Distribution Management 41(8), 596-626.

Hall, S., 1997. The Spectacle of the 'Other'. In: Hall, S. (ed.). Representation: Cultural Representations and Signifying Practices. London; Thousand Oaks; New Delhi: Sage, 223-279.

Harcourt W., Nelson I. L., 2015. Practising Feminist Political Ecologies: Moving Beyond the 'Green Economy'. Chicago: University of Chicago Press.

Hayes-Conroy A., Hayes-Conroy J., 2008. Taking Back Taste: Feminism, Food and Visceral Politics. Gender, Place \& Culture 15(5), 461-73.

Herzfeld, M., 2005. Cultural intimacy: Social poetics in the nation-state. New York: Routledge.

Hickey, G. C., 1967. Accommodation in South Vietnam: The key to Sociopolitical Solidarity. Santa Monica: The RAND Corporation.

Higgins, R. 2008. Negotiating the Middle: Interactions of Class, Gender and Consumerism among the Middle Class in Ho Chi Minh City, Viet Nam. Doctoral dissertation submitted to the Department of Anthropology, University of Arizona.

Hofman, I., Ho, P., 2012. China's 'Developmental Outsourcing': A critical examination of Chinese global 'land grabs' discourse. The Journal of Peasant Studies 39(1), 1-48.

Holt Giménez, E., Shattuck, A., 2011. Food crisis, food regimes and food movements: rumbling of reform tides of transformation? The Journal of Peasant Studies 38(1), 109-144.

Inglis, D., Gimlin, D. L., 2009. Food Globalizations: Ironies and Ambivalences of Food, Cuisine and Globality. In: Inglis, D., Gimlin, D.L. (eds.). The Globalization of Food. Oxford; New York: Berg, 3-44.

Jackson, P., 2015. Anxious Appetites: Food and Consumer Culture. London; New York: Bloomsbury.

Jamieson, N. J., 1995. Understanding Vietnam. Berkeley: University of California Press.

Jenks, C., 2003. Transgression. Key Ideas. London: Routledge.

King, V., Phuong An Nguyen, Nguyen Huu Minh, 2008. Professional middle class youth in postreform Vietnam: Identity, continuity and change. Modern Asian Studies 42(4), 783-813.

Kjærnes, U., Harvey, M., Warde, A., 2007. Trust in food: a comparative and institutional analysis. Basingstoke; New York: Palgrave Macmillan. 
Klein, J.A., 2014. Introduction: Cooking, Cuisine and Class and the Anthropology of Food. In: Klein, J., Murcott, A., Goody, J. (eds.). Food consumption in global perspective: essays in the anthropology of food in honour of Jack Goody. Consumption and public life. Basingstoke; New York: Palgrave Macmillan, 1-24.

Kurfürst, S., 2012. Informality as a strategy: Street traders facing constant insecurity. In: McFarlane C., Waibel M. (eds.). Urban Informalities: Reflections on the Formal and Informal. Farnham: Ashgate, 89-111.

Lamont, M., Molnár V., 2002. The Study of Boundaries in Social Sciences. Annual Review of Sociology 28, 167-195.

Lavin, C., 2013. Eating Anxiety: The Perils of Food Politics. Minneapolis: University of Minnesota Press.

LeBesco, K., 2011. Neoliberalism, Public Health, and the Moral Perils of Fatness. Critical Public Health 21(2), 153-164.

Leshkowich, A., 2012. Women, Buddhist, entrepreneur: Gender, moral, values, and class anxiety in late socialist Vietnam. Journal of Vietnamese Studies 1(1-2), 277-313.

Lévy-Strauss, C., 1997. The Culinary Triangle. In: Counihan, C., Van Esterik, P. (eds.). Food and Culture. A Reader. London; New York: Routledge, 28-35. Lupton, D., 1996. Food, the Body, and the Self. London; Thousand Oaks: Sage Publications.

Lupton, D., 2013. Fat. Abingdon; New York: Routledge.

Marzin, J., Michaud, A., 2016. Evolution of Rural Development Strategies and Policies. Lessons from Vietnam. Document de travail ART-Dev 2016-5, http://agritrop.cirad.fr/582603/1/Marzin\%20Michaud\%202016\%20 Rural\%20development\%20strategies\%20Vietnam\%20def.pdf (accessed 27.02.2018).

McMichael, P., 2009. A food regime genealogy. The Journal of Peasant Studies 36(1), 139-169.

McMichael, P., 2012. Development and Social Change. A global perspective. 5th ed. London: Sage.

Mennell, S., Murcott, A., Otterloo, A.H. van, 1992. The sociology of food: eating, diet, and culture. London; Newbury Park: Sage.

Metzl, J., Kirkland R. A. (eds.), 2010. Against Health: How Health Became the New Morality. Biopolitics, Medicine, Technoscience, and Health in the 21st Century. New York: New York University Press.

Mintz, S. W. 1985. Sweetness and Power: The Place of Sugar in Modern History. New York: Viking Penguin. 
Mintz, S. W., Du Bois, C. M., 2002. The Anthropology of Food and Eating. Annual Review of Anthropology 31, 99-119.

Mittal, A., 2009. The Blame Game: Understanding Structural Causes of the Food Crisis. In: Clapp, J. and Cohen, M. J. (eds.). The Global Food Crisis: Governance Challenges and Opportunities. Waterloo: Wilfrid Laurier University Press, 13-28.

Moeckli, J., Braun, B., 2001. Gendered natures: feminism, politics and social natures. In: Castree, N., Braun, B. (eds.). Social Nature: theory, practice and politics. Malden: Blackwell. 112-132.

Moustier, P., Phan Thi Giac Tam, Dao The Anh, Vu Trong Binh, Nguyen Thi Tan Loc, 2010. The role of farmer organizations in supplying supermarkets with quality food in Vietnam. Food Policy 35(1), 69-78.

Murcott, A. (ed.), 1983. The Sociology of food and eating: essays on the sociological significance of food. Aldershot: Gower.

Nestlé, M. 2013. Food politics. How the Food Industry Influences Nutrition and Health, Revised and Expanded Tenth Anniversary Edition. Berkeley; London: University of California Press.

Ngo Vinh Long, 1993. Reform and Rural Development: Impact on Class, Sectoral, and Regional Inequalities. In: Turley, W.S., Selden, M. (eds.). Reinventing Vietnamese socialism: doi moi in comparative perspective. Boulder: Westview Press, 165-207.

Nguyen Cong Khan, Ha Huy Khoi, 2008. Double burden of malnutrition: the Vietnamese perspective. Asia Pacific Journal of Clinical Nutrition 17(S1), $116-118$.

Nguyen Van Suu, 2009. Industrialization and Urbanization in Vietnam: How Appropriation of Agricultural Land Use Rights Transformed Farmers' Livelihoods in a Peri-Urban Hanoi Village? Final Report of an EADN Individual Research Grant Project, EADN Working Paper 38.

Parsons, J. M., 2015. Gender, class and food: families, bodies and health. London; New York: Palgrave Macmillan (Palgrave Macmillan Studies in Family and Intimate Life).

Popkin, S. L., 1979. The Rational Peasant. The Political Economy of Rural Society in Vietnam. Berkeley; London: University of California Press.

Poulain, J.-P., 2017. The Sociology of Food: Eating and the Place of Food in Society. London; New York: Bloomsbury Academic.

Probyn, E., 2000. Carnal Appetites: Food sex identities. London; New York: Routledge.

Ritzer, G., 1993. The McDonaldization of Society. Newbury Park: Pine Forge Press. 
Rozin, P. 1976. The Selection of Foods by Rats, Humans, and Other Animals. In: Rosenblatt, J. S., Hinde, R. A., Shaw, E. and Beer, C. (eds): Advances in Study of Behaviour, Volume 6. New York, San Francisco, London: Academic Press, 21-76.

Schwenkel, C., Leshkowich, A.M., 2012. Guest Editors' Introduction: How Is

Neoliberalism Good to Think Vietnam? How Is Vietnam Good to Think Neoliberalism? positions 20(2), 379-401.

Scott, J. C., 2009. The Art of Not Being Governed: An Anarchist History of Upland Southeast Asia. New Haven: Yale University Press (Yale Agrarian Studies Series).

Simmons, L., Scott, S., 2007. Health concerns drive safe vegetable production in Vietnam. Leisa Magazine 23(3), 22-23.

Slocum, R., Saldanha A. (eds.), 2013. Geographies of Race and Food: Fields, Bodies, Markets. Farnham; Burlington: Ashgate (Critical Food Studies).

Smajgl, A., To Quan Toan, Dang Kieu Nhan, Ward, J., Nguyen Hieu Trung, Le Quang Tri, Van Pham Dang Tri, Pham Thanh Vu, 2015. Responding to rising sea levels in the Mekong Delta. Nature Climate Change 5, 167-174.

Sobal, J., 1999. Food System Globalization, Eating Transformations, and Nutrition Transition. In: Grew, R. (ed.). Food in Global History. Boulder: Westview Press, 171-193.

Sutton, D. E., 2001. Remembrance of Repasts. An Anthropology of Food and Memory. Oxford: Berg.

Taylor, P., 2004. Preface. In: Taylor, P. (ed.). Social inequality in Vietnam and the challenges to reform. Singapore: Institute of Southeast Asian Studies, xi-xii.

Taylor, P., 2007. Cham Muslims of the Mekong Delta: Place and Mobility in the Cosmopolitan Periphery. Honolulu: University of Hawaii Press (ASAA Southeast Asia Publications Series).

TQ Cuong, Dibley, M.J., Bowe, S., Tran TM Hanh, TT Loan, 2007. Obesity in adults: an emerging problem in urban areas of Ho Chi Minh City, Vietnam. European Journal of Clinical Nutrition 61(5), 673-681.

Tran Thi Thu Trang, 2011. Food Security versus Food Sovereignty: Choice of Concept, Policies, and Classes in Vietnam's Post-Reform Economy. Kasarinlan - Philippine Journal of Third World Studies 26(1-2), 68-88.

Twigg, J., 1983. Vegetarianism and the meanings in meat. In: Murcott, A. (ed.). The sociology of food and eating: essays on the sociological significance of food. Aldershot: Gower, 18-30. 
Van Nguyen-Marshall, Drummond, L. B. W., Bélanger, D. (eds.), 2012. The Reinvention of distinction: modernity and the middle class in urban Vietnam. Dordrecht: Springer (ARI -Springer Asia Series).

Vann, E. F., 2005. Domesticating consumer goods in the global economy: Examples from Vietnam and Russia. Ethnos 70(4), 465-488.

Vietnam Ministry of Health. 2012. General Nutrition Survey 2009-2010. Hanoi: Medical Publishing House.

Walls, H. P., Peeters, A., Pham Thai Son, Ngoc Quang Nguyen, Nguyen Thi Thu Hoai, Do Doan Loi, Nguyen Lan Viet, Pham Gia Khai, Reid, C. M., 2009. Prevalence of underweight, overweight and obesity in urban Hanoi, Vietnam, Asia Pacific Journal of Clinical Nutrition 18(2): 234-239.

Walravens, T., 2013. Japan facing a rising China: food safety as a framework for Japanese identity formation. Acta Asiatica Varsoviensia 26, 115-135.

Warde, A., 1997. Consumption, Food and Taste. Manchester: Sage Publications. Watson, J. L., 1997. Golden Arches East: McDonald's in East Asia. Stanford: Stanford University Press.

Weis, T., 2013. The Meat of the Global Food Crisis. Journal of Peasant Studies 40(1), 65-85.

Wertheim-Heck, S. C. O., 2015. We have to eat, right? Food safety concerns and shopping for daily vegetables in modernizing Vietnam. Ph.D.-Thesis, Wageningen University.

WHO - World Health Organization, 2000. Obesity: Preventing and Managing the Global Epidemic. Report of a WHO Consultation. Geneva: World Health Organization.

Wilk, R., 2009. Difference on the Menu: Neophilia, Neophobia and Globalization. In: Inglis, D., Gimlin, D.L. (eds.). The Globalization of Food. Oxford; New York: Berg, 185-196.

Yan, Y. 2008. Of Hamburger and social space: Consuming McDonald's in Beijing. In: Counihan, C., Esterik, P. van (eds.). Food and Culture: A Reader. New York: Routledge, 500-522.

Yu, B., Zhu, T., Breisinger, C., Nguyen Manh Hai, 2010. Impacts of climate change on agriculture and policy options for adaptation. IFPRI (International Food Policy Research Institute) Discussion Paper 01015.

Zhang, H., 2016. The GMO Controversy in China: More than Food Security. In: IPP Review, 15.03.2016, http://ippreview.com/index.php/Home/Blog/ single/id/70.html (accessed 11.05.17). 
Open Access This chapter is licensed under the terms of the Creative Commons Attribution 4.0 International License (http://creativecommons.org/licenses/ by/4.0/), which permits use, sharing, adaptation, distribution and reproduction in any medium or format, as long as you give appropriate credit to the original author(s) and the source, provide a link to the Creative Commons licence and indicate if changes were made.

The images or other third party material in this chapter are included in the chapter's Creative Commons licence, unless indicated otherwise in a credit line to the material. If material is not included in the chapter's Creative Commons licence and your intended use is not permitted by statutory regulation or exceeds the permitted use, you will need to obtain permission directly from the copyright holder.

(c) (i) 